\title{
Leren op het werk: Een handelingstheoretisch perspectief
}

\author{
Toon Taris, Michiel Kompier, Etty Wielenga-Meijer*
}

In deze studie wordt de relatie tussen taakkenmerken en het leergedrag van taakuitvoerders bezien vanuit twee theoretische perspectieven. Karasek en Theorell's (1990) Demand-Control-(DC)-model stelt dat leergedrag vooral zal optreden wanneer werknemers geconfronteerd worden met zowel hoge taakeisen als veel regelmogelijkheden. We bespreken het bewijs voor deze assumptie en concluderen dat het DC-model weinig inzicht biedt in de manier waarop het leergedrag wordt beïnvloed door taakkenmerken. Bovendien biedt het DC-model geen ruimte voor individuele verschillen in leergedrag. Vervolgens bespreken we leergedrag vanuit een handelingstheoretisch perspectief. Vanuit een dergelijk perspectief kunnen de effecten van taakkenmerken op leergedrag alsmede de rol van persoonsvariabelen aanzienlijk beter worden begrepen. Ten slotte presenteren we een model waarin handelingstheoretische inzichten worden geïntegreerd met in onderzoek naar het DC-model verkregen empirische bevindingen.

Trefwoorden: leergedrag, handelingstheorie, Demand-Control-model, werkkenmerken

* Toon Taris, Radboud Universiteit Nijmegen, Sectie Arbeids- en Organisatiepsychologie. Correspondentieadres: Dr. T. Taris, Radboud Universiteit Nijmegen, Sectie Arbeids- en Organisatiepsychologie, Postbus 9104, 6500 HE Nijmegen. Telefoon: (024) 3612639, e-mail: t.taris@psych.ru.nl. Michiel Kompier, Radboud Universiteit Nijmegen, Sectie Arbeids- en Organisatiepsychologie.

Etty Wielenga-Meijer, Radboud Universiteit Nijmegen, Sectie Arbeids- en Organisatiepsychologie. 
Whenever you are asked if you can do a job, tell 'em, 'Certainly I can!' - Then get busy and find out how to do it.

Theodore Roosevelt, $26^{\text {ste }}$ president van Amerika (I90I-1909)

\section{Inleiding}

Arbeid speelt een centrale rol in het leven van alledag. Buiten weekenden en vakanties besteden veel volwassenen ongeveer de helft van de tijd dat zij wakker zijn op het werk. Daarnaast heeft werk een belangrijk effect op het functioneren in andere domeinen, zoals de thuissituatie (Geurts \& Demerouti, 2003). Het is daarom niet verrassend dat onderzoekers steeds meer geïnteresseerd raken in de effecten van de psychosociale werkomgeving op de gezondheid en het welbevinden van werknemers. Het onderzoek op dit terrein is echter vooral gericht op de relatie met stress en onwelbevinden, wellicht omdat fenomenen zoals hoge werkdruk, stress en vermoeidheid het laatste decennium een groot maatschappelijk probleem vormden (Merllié \& Paoli, 20or). Dat betekent echter niet dat onderzoek zich uitsluitend op dergelijke aspecten zou moeten richten. Moderne conceptualisaties van arbeidsgebonden welzijn omvatten bijvoorbeeld, naast negatieve aspecten zoals stress, ook positieve aspecten als aspiratie (de mate waarin taakuitvoerders uitdagende doelen nastreven op het werk), zelfvertrouwen en competentie (zie Van Horn, Taris, Schaufeli \& Schreurs, 2004).

Een van de belangrijkste positieve aspecten van werkgebonden welzijn betreft de mate waarin taakuitvoerders zich kunnen ontwikkelen. Leergedrag zou daarom ook in de arbeids- en gezondheidspsychologie een belangrijk onderwerp moeten zijn, maar is dat tot op heden echter niet. Doel van dit artikel is een aanzet te geven tot verdere arbeids- en gezondheidspsychologische theorievorming en meer onderzoek op dit terrein. We bespreken eerst een belangrijk arbeids- en gezondheidspsychologisch model (Karasek \& Theorell, I990, Demand-Control-[DC]-model) dat bij wijze van uitzondering niet alleen gericht is op stress en onwelbevinden, maar ook positieve uitkomsten als leergedrag beschrijft; volgens Kwakman (I999) is dit model 'bij uitstek' geschikt om leren te onderzoeken (p. I3I). Daarna komt een alternatieve benadering aan de orde (de handelingstheorie, Frese \& Zapf, I994; Hacker, I998) die beschrijft hoe en waarom werkkenmerken gerelateerd zijn aan leergedrag. Ten slotte geven we aan in welke richting onderzoek op dit terrein naar onze mening zou moeten gaan.

\section{Werkkenmerken en leergedrag: het Demand-Control-model}

In deze studie wordt verondersteld dat er een relatie bestaat tussen taakkenmerken en leergedrag. Die gedachte is niet nieuw. Zo vonden Berlew en Hall (I966) dat nieuwe managers die hun baan 'uitdagend' vonden, na verloop van tijd beter presteerden dan hun tegelijk aangenomen collega's. Voor zover die toename in prestatie het resultaat is van leerprocessen, suggereert dit resultaat dat hoge taak- 
eisen een positief effect kunnen hebben op de leer- en ontwikkelingsmogelijkheden. McCauley, Ruderman en Morrow (1994) ontwikkelden een instrument om de ontwikkelingsmogelijkheden van managementbanen te beoordelen, de Developmental Challenge Profile, waarin taakkenmerken een belangrijke plaats innemen. In deze en vergelijkbare andere studies werd echter geen systematische, op theorie gebaseerde analyse gepresenteerd van de taakkenmerken die van invloed zijn op het leren en de ontwikkeling van werknemers. De vraag die rijst is, wat zijn de belangrijkste taakkenmerken die gerelateerd zijn aan het leren van werknemers? Voor zover de arbeids- en gezondheidspsychologie zich met dit onderwerp heeft beziggehouden, is dat vooral binnen Karaseks (1979) Demand-Control-model en de uitbreiding daarvan, het Demand-Control-Support-(DCS)-model (Karasek \& Theorell, r990), geweest. Kortheidshalve beperken we ons tot het DC-model; de voorspellingen daarvan verschillen niet essentieel van hetgeen door het DCS-model wordt verondersteld.

Volgens het DC-model kan een werkomgeving gekarakteriseerd worden in termen van de combinatie van psychologische takkeisen (demands) en de mogelijkheden die taakuitvoerders hebben om deze eisen te vervullen (control, gewoonlijk gemeten als de zeggenschap die zij hebben over de manier waarop en de volgorde waarin zij hun werkzaamheden kunnen uitvoeren, alsmede de mate waarin zij hun vaardigheden kunnen gebruiken). Op basis van deze twee werkkenmerken kunnen vier typen banen worden onderscheiden. Taakuitvoerders in banen met hoge taakeisen en weinig controle zouden veel stress ervaren, omdat zij niet optimaal tegemoet kunnen komen aan de eisen die het werk aan hen stelt. Het gebrek aan controle leidt ertoe dat deze werknemers niet kunnen experimenteren met verschillende manieren om hun taken uit te voeren, wat betekent dat zij weinig mogelijkheden hebben om nieuwe vaardigheden te verwerven. Banen waarin hoge taakeisen gecombineerd worden met veel controlemogelijkheden zouden taakuitvoerders daarentegen zowel uitdaging (in de vorm van hoge takkeisen) bieden als goede mogelijkheden om aan die taakeisen tegemoet te komen. Deze werknemers zouden relatief weinig stress ervaren, en kunnen experimenteren met nieuwe manieren om hun taken uit te voeren. Daarom hebben deze werknemers uitstekende kansen om nieuwe vaardigheden te verwerven, wat weer zou leiden tot gevoelens van zelfvertrouwen en competentie. Banen met lage taakeisen en weinig controlemogelijkheden bieden weinig uitdaging en zullen, vanwege het gebrek aan eisen, gewoonlijk geen stress opleveren. Taakuitvoerders in deze banen kunnen echter niet experimenteren met nieuwe manieren om hun werk uit te voeren en hebben dus weinig gelegenheid om zich verder te ontwikkelen. Ten slotte zullen ook banen met weinig taakeisen en veel controlemogelijkheden weinig stress opleveren. Werknemers in dergelijke banen kunnen uitgebreid experimenteren met verschillende manieren om hun werk uit te voeren, en hebben veel gelegenheid om nieuwe vaardigheden te verwerven (Bandura, 1998). Dit positieve effect zou echter weer teniet worden gedaan door het ontbreken van uitdaging in het werk vanwege de lage taakeisen. Samenvattend, leergedrag en de daarmee samenhangende positieve consequenties zullen volgens het DC-model vooral optreden als taakuitvoerders geconfronteerd worden met hoge (maar niet excessief hoge) taakeisen in combinatie met veel controlemogelijkheden; leergedrag zal grotendeels afwezig zijn bij gebrek aan takeisen en controle (de actief-leren- 
hypothese). Stress zal optreden wanneer werknemers hoge taakeisen ervaren en over te weinig controle beschikken om deze eisen te kunnen vervullen; werknemers in banen met weinig taakeisen en veel controle zullen daarentegen geen stress ervaren (de strainhypothese).

Omdat stress en leergedrag beide het gevolg zijn van bepaalde combinaties van takkeisen en controlemogelijkheden zouden zij moeten samenhangen. Hoewel Karasek en Theorell (1990) stellen dat 'skill acquisition mechanisms are independent of [...] the residual psychological strain mechanism' (p. 38, onze cursivering), veronderstellen zij elders inderdaad dat beide fenomenen aan elkaar gerelateerd zijn. Stress zou ertoe leiden dat takuitvoerders zich met andere zaken dan de taak bezig gaan houden en zou verhinderen dat zij experimenteren met nieuwe manieren om hun taak uit te voeren ('strain inhibits learning', Karasek \& Theorell, I990, p. Ioo). Omgekeerd zal leergedrag leiden tot minder stress ('learning inhibits stress', p. IoI). Meer kennis en grotere vaardigheden stellen takuitvoerders immers in staat om beter met de taakeisen om te gaan, wat ertoe zal leiden dat zij deze eisen als minder stresserend zullen beschouwen.

\subsection{Wat is 'actief leergedrag' eigenlijk?}

Tot nu toe zijn we niet ingegaan op de vraag wat 'actief leergedrag' is. Marsick en Watkins (1990) onderscheiden formeel en informeel leergedrag. Formeel leergedrag vindt vooral plaats in zeer gestructureerde omgevingen (bijvoorbeeld in de context van een cursus of training); informeel leergedrag is daarentegen niet geïnstitutionaliseerd, maar eerder het resultaat van het verwerken van de ervaringen die het individu tijdens het werk opdoet. Karasek en Theorell (1990) beschrijven het actieflerenconcept in brede termen, waarbij ze zowel refereren aan de veronderstelde uitkomsten van dit gedrag als aan het concept zelf. $Z$ ij spreken bijvoorbeeld over (I) het verwerven van nieuwe gedragspatronen en vaardigheden, dan wel de motivatie daartoe; (2) het effectief kunnen oplossen van problemen op het werk, dan wel het zich kunnen aanpassen aan de omgeving; en (3) motivatie en betrokkenheid in het algemeen. Er kunnen dus tenminste drie verschillende aspecten aan actief leergedrag worden onderscheiden, waarbij Karasek en Theorell de eerstgenoemde twee facetten als de beste representant van het door hen bedoelde begrip lijken te zien: 'our model of motivation is that it is an environmentally facilitated, active approach toward learning new behavior patterns or solving new problems' (I990, p. I70, onze cursivering). Deze definitie van actief leergedrag stemt overeen met die van Weiss (I990, p. I73), die stelde dat 'learning is a relatively permanent change in knowledge or skill produced by experience', en suggereert dat actief leergedrag vooral een vorm van informeel leren is. Volgens McCall, Lombardo en Morrison (I988) draagt dergelijk informeel leren - gemeten in termen van ervaring - duidelijk meer bij aan de ontwikkeling van managers dan formele trainingsprogramma's.

Actief leergedrag is een theoretisch concept dat niet direct kan worden waargenomen, en dat moet worden afgeleid uit zijn veronderstelde gevolgen. Blijkens de literatuur omvatten deze gevolgen vooral specifieke en direct aan leergedrag te relateren uitkomsten (zoals het beheersen van bepaalde vaardigheden en daaraan gerelateerde gevoelens van competentie). Karasek en Theorell (I990, p. IOI) stellen bijvoorbeeld dat het 'cumulative result of newly learnt behavior patterns is to increase skills and 
feelings of mastery'. Zij beschouwen toename van competentie en zelfvertrouwen dus als de belangrijkste persoonlijke uitkomsten van actief leergedrag.

\subsection{Ondersteuning voor het DC-model}

De laatste 25 jaar heeft een groot aantal studies de strainhypothese van het DC-model getoetst. Daarbij bleken de verschillende indicatoren van stress inderdaad positief samen te hangen met takkeisen en negatief met controlemogelijkheden (De Lange et al., 2003; Van der Doef \& Maes, I999, voor overzichtsstudies). De actief-lerenbypothese is tot op heden echter zelden onderwerp van onderzoek geweest. Elders (Taris \& Kompier, 2004) hebben we de studies op dit terrein geïnventariseerd. In de achttien door ons gevonden studies werd de actief-lerenhypothese in totaal dertig maal getoetst (in veel studies waren meerdere aan actief leren gerelateerde concepten opgenomen). Negentien toetsen (63,3\%) ondersteunden de actief-lerenhypothese, in de zin dat de veronderstelde verbanden tussen controlemogelijkheden en taakeisen enerzijds en actief leren anderzijds werden gevonden. In de resterende elf gevallen werd gewoonlijk een positief verband tussen controle en de betreffende uitkomstvariabele gevonden, maar was de hoeveelheid taakeisen irrelevant.

Op het eerste gezicht lijkt het bewijs voor de actief-lerenhypothese redelijk sterk; vooral het hebben van controle over de eigen werkzaamheden is van belang, terwijl de effecten van taakeisen minder consistent zijn. Eén verklaring voor dit laatstgenoemde gebrek aan consistentie is dat de relatie tussen taakeisen en leergedrag kromlijnig is. Karasek (1998) stelt dat actief leergedrag zal optreden 'when control on the job is high, and psychological demands are also high, but not overwhelming' (p. 34.7); wellicht waren de taakeisen in de betreffende steekproeven te hoog. Op het tweede gezicht is het bewijs echter minder overtuigend, vooral vanwege methodische en conceptuele problemen. De belangrijkste methodische tekortkoming betreft de afwezigheid van longitudinale onderzoeksopzetten. Slechts vier van de achttien onderzochte studies kenden een longitudinaal design; in de overige gevallen kunnen geen causale conclusies worden getrokken. Taris en Kompier (2004) laten zien dat juist de resultaten van deze longitudinale studies weinig ondersteuning bieden voor de actief-lerenhypothese, zodat onduidelijk is of de relaties tussen taakkenmerken en leergedrag causaal geïnterpreteerd kunnen worden.

De conceptuele problemen van het eerdere onderzoek naar actief leergedrag zijn nog belangrijker, en betreffen (I) de validiteit van de onafhankelijke variabelen (taakkenmerken), (2) de validiteit van de uitkomstmaten, (3) de aard van de relatie tussen stress en leergedrag, en (4) de conceptualisatie van de leerhypothese; welke mechanismen zijn verantwoordelijk voor de effecten van taakkenmerken op het leergedrag? De eerste drie aspecten kunnen worden besproken in de context van het DC-model. Het laatste aspect vereist een heroriëntatie op de relatie tussen werkkenmerken en leergedrag en wordt in een aparte paragraaf uitgewerkt.

(I) De constructvaliditeit van controlemogelijkheden en taakeisen. In het DC-model wordt controle gemeten als de combinatie van de zeggenschap die taakuitvoerders hebben over hun taken en de uitvoering daarvan (decision authority) alsmede de mate waarin zij gebruikmaken van hun vaardigheden (skill discretion). Het voordeel van het combineren van beide aspecten is onduidelijk. Daarnaast kan het concept vaardigheidsgebruik operationeel overlap vertonen met meting van actief leerge- 
drag, wanneer dat wordt gemeten als het verwerven van nieuwe vaardigheden. Een vergelijkbaar probleem betreft de meting van taakeisen. In het instrument van Karasek (1985) wordt vooral gemeten hoe snel men moet werken en hoeveel men moet doen. Het lijkt echter belangrijk om niet alleen kwantitatieve taakeisen, maar ook emotionele, kwalitatieve, en wellicht nog andere taakeisen te meten (vergelijk Kristensen, Bjorner, Christensen \& Borg, 2004).

(2) De constructvaliditeit van de uitkomstvariabelen. Veel evidentie voor de actieflerenhypothese is afkomstig van studies waarin algemene, a-specifieke maten voor leergedrag worden bestudeerd (zoals zelfvertrouwen, satisfactie, betrokkenheid), in plaats van specifiek aan leergedrag toe te schrijven uitkomsten (Taris \& Kompier, 2004). De scores op dergelijke algemene uitkomstmaten kunnen het resultaat zijn van andere factoren dan alleen taakeisen en regelmogelijkheden. Het is bijvoorbeeld uiterst merkwaardig dat zowel de actief-lerenhypothese als de strain-hypothese getoetst is én ondersteund werd met satisfactie als criterium (zie De Lange et al., 2003; Van der Doef \& Maes, I999); uitkomsten die de strain-hypothese bevestigen verschillen immers van uitkomsten die de actief-lerenhypothese ondersteunen. Dergelijke a-specifieke variabelen lijken dus minder geschikt voor het toetsen van de actief-lerenhypothese dan inhoudelijk dichter bij het leergedrag liggende concepten.

(3) De relatie tussen stress en leergedrag. Er is nauwelijks onderzoek verricht naar de relatie tussen werkstress en leergedrag. Ons zijn slechts drie studies naar dit onderwerp bekend. Parker en Sprigg (1999) vonden in een cross-sectionele studie dat weinig stress samenging met veel gevoelens van mastery (een vorm van werkgerelateerd zelfvertrouwen, wat volgens Karasek \& Theorell [I990] een belangrijke uitkomst van actief leren is). Holman en Wall (2002) stelden zowel dat stress ervoor zorgde dat taakuitvoerders weinig leergedrag (gemeten in termen van zelfvertrouwen en het gebruik van vaardigheden) vertoonden, alsook dat veel leergedrag ertoe zou leiden dat taakuitvoerders weinig stress ervaarden. Ten slotte vonden Taris en Feij (2005) in een longitudinale studie dat stress op termijn gerelateerd was aan minder leergedrag; de omgekeerde relatie werd niet bevestigd. Gegeven deze wat ambigue bevindingen kan worden geconcludeerd dat stress en leergedrag samenhangen; de precieze dynamiek van deze samenhang is vooralsnog onduidelijk.

\subsection{De conceptualisatie van de leerhypothese}

De drie hierboven genoemde problemen vragen om meer en kwalitatief beter onderzoek naar de actief-lerenhypothese. Het vierde probleem met onderzoek naar deze hypothese betreft echter de conceptuele fundering ervan: welke mechanismen zijn nu precies verantwoordelijk voor de effecten van taakkenmerken op leergedrag? Eenvoudig gezegd stelt het DC-model dat werknemers met veel controlemogelijkheden en veel taakeisen zelf bepalen hoe ze met die eisen omgaan, wat ertoe kan leiden dat zij nieuwe gedragspatronen ontwikkelen (Karasek \& Theorell, I990, p. 92). We betwijfelen echter of meer onderzoek op basis van dit model ons inzicht in de relatie tussen werkkenmerken, stress en leergedrag veel verder zal brengen. In essentie is het DC-model een stimulus-responsemodel, waarin taakuitvoerders passieve ontvangers van omgevingsinvloeden zijn; gegeven een bepaalde context (de stimulus) zullen alle taakuitvoerders een bepaalde mate van leergedrag (de respons) ver- 
tonen. De intrapersoonlijke mechanismen die bepaalde combinaties van taakeisen en regelmogelijkheden verbinden met (variaties in) leergedrag worden niet gespecificeerd, wat dit deel van het DC-model in een black box verpakt. Aldus maakt het model niet duidelijk waarom en hoe bepaalde taakkenmerken leergedrag oproepen. Een verwant probleem is dat het DC-model interpersoonlijke verschillen grotendeels negeert. Het model verklaart niet waarom taakuitvoerders verschillen in de mate waarin zij leergedrag vertonen, zelfs als de condities waaronder zij werkzaam zijn gelijk zijn. Men kan met Karasek (I998) meevoelen waar deze 'find[s] it hard to accept that the majority of stress reactions develop because common personality types habitually misinterpret real world stresses or are oversensitive to them' (p. 34.II), maar dat is vooralsnog een empirische kwestie. Eerder onderzoek naar de strain-hypothese heeft bijvoorbeeld laten zien dat de sterkte van de effecten van taakeisen en controle afhankelijk was van copingstijl (De Rijk, Le Blanc, Schaufeli \& De Jonge, I998), terwijl Parker en Sprigg (I999) vonden dat de effecten van taakeisen en regelmogelijkheden op leergedrag gemodereerd werden door de mate van proactiviteit van de taakuitvoerder. Modellen die de effecten van werkkenmerken op werk- en gezondheidsuitkomsten beschrijven, kunnen interpersoonlijke verschillen dus niet zomaar terzijde schuiven.

Beide problemen (het negeren van intrapersoonlijke mechanismen en interpersoonlijke verschillen) zijn zowel praktisch als wetenschappelijk relevant. Vanuit wetenschappelijk oogpunt is het belangrijk om te weten welke factoren het leergedrag beïnvloeden; we moeten daarom weten welke psychologische mechanismen het leergedrag reguleren. Praktisch gesproken is een goed begrip van de relatie tussen werkkenmerken, interpersoonlijke verschillen en leergedrag van belang bij het (her)ontwerpen van taken; zo kunnen we bijvoorbeeld vooraf beter inschatten of het vergroten van controlemogelijkheden ertoe zal leiden dat taakuitvoerders meer leergedrag zullen gaan vertonen.

\section{Een handelingstheoretisch perspectief op leergedrag}

In deze paragraaf presenteren we een ver uitgewerkt theoretisch kader dat tot op heden slechts spaarzaam wordt gebruikt in de arbeids- en gezondheidspsychologie, namelijk de in voormalig Oost-Duitsland ontwikkelde actie- of handelingstheorie (HT, Frese \& Zapf, I994; Hacker, I998). We denken dat de HT kan helpen ons begrip van leergedrag te vergroten, omdat deze benadering inzicht biedt in de intrapersoonlijke processen die werkkenmerken verbinden met leergedrag, alsmede laat zien welke typen interpersoonlijke verschillen relevant kunnen zijn voor het verwerven van nieuwe vaardigheden. Hieronder bespreken we (I) de assumpties van de HT; (2) de manier waarop leergedrag (Persönlichkeitsförderlichkeit, ofwel persoonlijkheidsontwikkeling) in de HT wordt geconceptualiseerd, in vergelijking met het actief leergedrag in het DC-model; (3) de condities waaronder leergedrag zal optreden, en (4) de gevolgen daarvan voor het leren van nieuwe vaardigheden. 


\subsection{Handelingstheorie: handelen als doelgericht gedrag}

De HT houdt zich bezig met de cognitieve regulatie van taakgedrag, in casu de handelingen die werkenden uitvoeren. Deze handelingen worden opgevat als doelgericht gedrag; het uiteindelijke doel van arbeid is immers het produceren van een product of dienst (Frese \& Zapf, 1994). Doelen kunnen bijvoorbeeld zijn het schrijven van een onderzoeksvoorstel, of het verwerven van nieuwe vaardigheden om zo de eigen werkprestaties te verhogen. De HT veronderstelt dat het proces dat leidt tot verwezenlijking van deze doelen kan worden opgedeeld in vijf stadia (de feedbackcyclus, Volpert, I97I): (I) keuze van het te verwezenlijken doel, (2) oriëntatie en prognose, (3) genereren van plannen, (4) uitvoering en bewaking van de voortgang van het gekozen plan, en (5) feedback. Idealiter volgen deze fasen elkaar op; in de praktijk kan een en ander uiteraard minder systematisch verlopen. In de eerste fase (doelkeuze) wordt het te verwezenlijken doel geselecteerd. Taken kunnen worden gedefinieerd in termen van de doelen die de taakuitvoerder moet bereiken. Het startpunt voor takkgedrag ligt dus in de te realiseren doelen. Dit betekent echter niet dat het handelen van taakuitvoerders uitsluitend wordt gestuurd door deze doelen. Integendeel, de HT veronderstelt dat taakuitvoerders actief vorm geven aan hun omgeving. Goed functionerende taakuitvoerders kunnen nieuwe uitdagingen gaan zoeken, vermoeide takuitvoerders kunnen hun taken bijvoorbeeld als belastender zien, enzovoort (De Lange et al., 2005, voor een overzicht van mogelijke mechanismen). Taakuitvoerders kunnen zo hun doelen bijstellen.

In de oriëntatie- en prognosefase oriënteert de takuitvoerder zich op eventuele nieuwe stimuli (taakeisen). De werksituatie kan snel veranderen; takuitvoerders moeten de gevolgen daarvan voor henzelf en de organisatie kunnen voorzien. In deze fase zoekt de taakuitvoerder actief naar informatie die kan helpen aan deze veranderingen en de gevolgen daarvan het hoofd te bieden. Deze informatie wordt verzameld en geordend op basis van bestaande kennis en het mentale model (dat wil zeggen, de schemata en analogieën) dat zij hebben betreffende het werkproces. De door de taakuitvoerder ondernomen handelingen (inclusief het gericht zoeken naar bepaalde informatie) zijn afhankelijk van deze kennis en modellen.

Op basis van deze informatie zullen taakuitvoerders een handelingsplan ontwikkelen (genereren van plannen). Dergelijke plannen verschillen in de mate van detail, tijdsplanning, en de mate waarin zij voorzien in mogelijke problemen bij de uitvoering ervan (Gollwitzer, 1999), alsmede in de mate waarin ze reeds geautomatiseerd zijn. Tijdens de uitvoering van het plan moeten takuitvoerders de mate waarin ze het gestelde doel naderen in de gaten houden, alsmede speuren naar mogelijkheden die zich voordoen om dat doel dichterbij te brengen.

Tenslotte, leren is onmogelijk zonder de resultaten van het eigen handelen te kennen (Bandura, 1997). Feedback is dus van essentieel belang: het laat zien met welk succes men bepaalde strategieën om een doel te behalen toepast, alsmede hoe ver men gevorderd is met het realiseren van dat doel. De uitkomst van dat vergelijkingsproces kan ertoe leiden dat men de gebruikte strategieën wijzigt, maar ook tot veranderingen in het te bereiken doel (waaronder wijziging van het doel, dan wel het formuleren van nieuwe doelen). In het laatste geval is de cyclus voltooid en begint men weer van voren af aan. 
Handelingsregulatie tijdens de feedbackcyclus. Het handelen in elk van de stadia van de feedbackcyclus wordt gereguleerd door cognities, die verschillen in de mate waarin zij aandacht en inspanning vereisen. Frese en Zapf (1994) onderscheiden vier niveaus waarop handelingen gereguleerd kunnen worden (vergelijk Hacker, I998; Roe \& Zijlstra, I99I). Het sensomotorische niveau heeft betrekking op handelingen gedurende welke vooral onbewuste, geautomatiseerde informatieverwerking plaatsvindt (zoals wandelen of schrijven). Informatie wordt hier parallel, snel, en zonder noemenswaardige inspanning verwerkt. Het niveau van de flexibele actiepatronen heeft betrekking op kant-en-klare, volgens vaste regels verlopende actieprogramma's die al beschikbaar zijn in het geheugen. Deze programma's zijn eerder samengesteld (oftewel geleerd) en moeten worden geactiveerd en geïntegreerd in een keten van handelingen die betrekking heeft op een specifieke situatie. Informatie kan bewust worden verwerkt, maar dat is niet altijd noodzakelijk. Een voorbeeld van regulatie op dit als $X$, dan $Y$-niveau is het remmen voor een rood stoplicht.

Het niveau van intellectuele actieregulatie heeft betrekking op gecontroleerde informatieverwerking. Op dit niveau worden nieuwe actieprogramma's ontworpen die worden getoetst door alle stadia van de feedbackcyclus te doorlopen. Deze programma's worden bewust en langzaam uitgevoerd, verlopen serieel (men kan niet twee dergelijke programma's tegelijkertijd uitvoeren), en vereisen inspanning, analyse en synthese van nieuwe informatie. Een nieuwe chauffeur van een koeriersdienst kan bijvoorbeeld een optimale route uitstippelen om zijn goederen af te leveren. De kwaliteit van een dergelijk actieplan is afhankelijk van het door de takuitvoerder gehanteerde mentale model van de uit te voeren taak. Dit mentale model kan worden gedefinieerd als een interne representatie van een extern systeem (bijvoorbeeld de taak), dat uit tenminste twee samenhangende variabelen bestaat (vergelijk Brewer, 2003). De juistheid en compleetheid van het mentale model bepaalt de kwaliteit van de actieplannen die in deze fase worden ontworpen; een incompleet en/of onjuist mentaal model kan ertoe leiden dat een bepaald actieplan in de praktijk niet zal werken. De chauffeur van de koeriersdienst in het bovenstaande voorbeeld kan bij het ontwerpen van een optimale route bijvoorbeeld vergeten rekening te houden met de op bepaalde tijden op bepaalde wegen bestaande filevorming, waardoor de kortste route niet altijd de snelste hoeft te zijn.

De drie hiervoor besproken regulatieniveaus vinden plaats in de context van een relatief concrete omgeving om een min of meer welomschreven doel te bereiken. Wanneer een dergelijk doel of omgeving afwezig is, zullen abstracte heuristieken worden gebruikt om handelingsplannen te genereren. Het heuristische niveau van actieregulatie heeft betrekking op abstracte redeneringen en beschouwingen betreffende de manier waarop een algemene klasse van problemen op een bepaald terrein aangepakt zou moeten worden, het toetsen van logische inconsistenties en het kiezen van abstracte, overkoepelende doelen. Onderzoekers kunnen bijvoorbeeld zoeken naar de beste manier om een bepaald probleem op te lossen (welk type onderzoeksdesign is het meest geschikt om bepaalde onderzoeksvragen aan te pakken?), of zich afvragen welke typen onderzoeksstrategieën en -onderwerpen de beste kans op publicaties in toptijdschriften opleveren.

Samenvattend, de tijdens het doorlopen van de feedbackcyclus uitgevoerde handelingen verschillen in de mate waarin zij bewuste regulatie vereisen. Verondersteld 
wordt dat de kans dat taakuitvoerders zullen leren in hun werk toeneemt naarmate hun werk meer gelegenheid biedt om hun handelingen op de twee hoogste niveaus te reguleren. Wanneer takuitvoerders hun eigen doelen kunnen bepalen, zijn er goede mogelijkheden om nieuwe vaardigheden te verwerven. Het kiezen van nieuwe doelen betekent immers dat nieuwe mentale modellen en handelingsplannen ontworpen moeten worden, en het uitvoeren daarvan kan weer vereisen dat taakuitvoerders nieuwe vaardigheden verwerven. De twee volgende paragrafen bespreken de relatie tussen werkkenmerken (regelmogelijkheden en regelvereisten) en leergedrag in meer detail.

\subsection{Een handelingstheoretisch perspectief op leren}

De HT is een ontwerpgerichte benadering waarin vooropstaat dat taken volledig moeten zijn (Hacker, I998). Taken zijn goed ontworpen wanneer zij uitvoerders de gelegenheid bieden om (I) alle stappen in de feedbackcyclus te doorlopen; en (2) alle regulatieniveaus te gebruiken. Wanneer aan deze twee vereisten is voldaan worden de kansen op persoonlijkheidsontwikkeling gemaximaliseerd. 'Persoonlijkheid' wordt hier opgevat als '... a set of cognitive and procedural skills developed in work, like problem-solving, social and general meta-cognitive skills' (Frese \& Zapf, I994, p. 294). Persoonlijkheidsontwikkeling refereert dus aan een toename van de cognitieve en procedurele vaardigheden van de taakuitvoerder. Twee kernelementen van deze definitie van persoonlijkheidsontwikkeling zijn: (I) vaardigheden nemen toe als functie van hetgeen men doet op het werk. Persoonlijkheidsontwikkeling is daarmee een label voor een type leren dat sterk lijkt op Karasek en Theorell's (I990) actief-lerenconcept; en (2) de aldus aangeleerde vaardigheden zijn ook toepasbaar in andere domeinen dan alleen het werk (spillover, Geurts \& Demerouti, 2003). De in de arbeidssituatie aangeleerde vaardigheden zouden bijvoorbeeld gegeneraliseerd kunnen worden naar een algemeen niveau van flexibel intellectueel functioneren. Merk op dat Karasek (1976) zijn actief-lerenhypothese reeds dertig jaar geleden toetste met gegevens over politieke participatie en vrijetijdsbesteding; ook in het DC-model wordt dus een dergelijke spillover van vaardigheden verondersteld.

Het is hier zinvol om onderscheid te maken tussen twee typen leergedrag. Ten eerste kan leren betrekking hebben op het vinden van oplossingen voor nieuwe problemen (i.c. het ontwikkelen van nieuwe actieprogramma's). Dit vereist gecontroleerde informatieverwerking op de twee hoogste regulatieniveaus, inclusief analyse en synthese van nieuwe informatie en abstract redeneren, maar ook toetsing van (delen van) oplossingen op hun werkzaamheid. Dit impliceert dat de feedbackcyclus doorlopen en herhaald moet worden totdat een effectief actieprogramma (de oplossing) is ontwikkeld. Vervolgens kan een tweede type leren plaatsvinden, namelijk het overbrengen van de handelingen die vereist zijn om een bepaald actieprogramma uit te voeren naar de twee laagste regulatieniveaus (routinisatie). Terwijl de uitvoering van een nieuw actieprogramma aanvankelijk veel aandacht zal vereisen (bijvoorbeeld leren schrijven), zullen de betreffende vaardigheden na oefening worden geautomatiseerd. Routinisatie refereert dus aan de mate waarin bewuste informatieverwerking nodig is om de handeling uit te voeren.

Waar het eerste type leren gericht is op het ontwikkelen van oplossingen, betreft het tweede type leren vooral het verbeteren van de efficiëntie van deze oplossingen. 
Vaak zijn beide typen leergedrag nodig voordat er prestatieverbetering zichtbaar is. Taakuitvoerders kunnen begrijpen wat de taak inhoudt en welke handelingen er moeten worden verricht om deze uit te voeren, maar dat betekent niet dat zij ook beschikken over de vaardigheden om het betreffende programma effectief en efficiënt uit te kunnen voeren. De trainer van een voetbalclub in de eredivisie kan bijvoorbeeld precies weten wat er moet gebeuren om de wedstrijd winnend af te sluiten, maar zal desalniettemin op het veld een modderfiguur slaan omdat hij niet (meer) over de vaardigheden beschikt om de betreffende handelingen snel uit te kunnen voeren.

Het actief-lerenconcept in het DC-model omvat beide typen leren (Karasek, I998). Een deel van de door Karasek en Theorell (1990) genoemde vormen van leergedrag heeft betrekking op het ontwikkelen van nieuwe actieprogramma's. Zij spreken bijvoorbeeld over het verwerven van nieuwe vaardigheden en het genereren van oplossingen voor nieuwe problemen. Andere door hen genoemde vormen van leren hebben eerder (zij het impliciet) betrekking op het routiniseren van vaardigheden. Uitkomsten van leergedrag als 'vergroting van het aantal confronteerbare uitdagingen' (p. 93) veronderstellen dat taakuitvoerders hun vaardigheden kunnen toepassen wanneer zij dat willen - maar hoe kan een uitdaging worden aangegaan als men wel weet hoe dat zou moeten, terwijl de vaardigheden om die uitdaging tot een goed einde te brengen ontbreken? Het begrip persoonlijkheidsontwikkeling in de handelingstheorie lijkt dus grotendeels samen te vallen met het in het DC-model gebruikte actief-lerenconcept, zowel in termen van de uitkomsten daarvan (ontwikkeling van vaardigheden en toepassing daarvan in zowel de werk- als de niet-werksfeer), als in termen van haar componenten (ontwikkeling van nieuwe actieprogramma's om problemen op te lossen, het routiniseren van bestaande programma's).

\subsection{Voorwaarden voor persoonlijkheidsontwikkeling}

De HT veronderstelt dat de kansen op persoonlijkheidsontwikkeling (in casu leren) toenemen wanneer taakuitvoerders de gehele feedbackcyclus kunnen doorlopen en hun werk alle vier regulatieniveaus omvat. De mate waarin aan deze twee voorwaarden is voldaan is afhankelijk van diverse factoren, waaronder (I) de regulatievereisten van de taak (de moeilijkheid en de complexiteit van de uit te voeren werkzaamheden - deels overlappend met de vaker gebruikte term takkeisen), (2) de regulatiemogelijkheden (waaronder controle dan wel regelmogelijkheden), (3) aspecten die het leren faciliteren (feedback), en (4) actiestijlen, die betrekking hebben op de manier waarop taakuitvoerders omgaan met de problemen en kansen die zich voordoen in hun werk.

Regulatievereisten: Taakeisen. De regulatievereisten van de taak beïnvloeden de manier waarop de handeling wordt georganiseerd. Eén belangrijke regulatievereiste betreft de complexiteit van de uit te voeren taak; welke en hoeveel beslissingen zijn noodzakelijk om de taak goed uit te voeren? Dit aspect is afhankelijk van het aantal verschillende na te streven doelen en handelingsplannen die met elkaar verenigd moeten worden, de mate waarin zij verschillen (dan wel overeenkomen), alsmede de relaties daartussen. Een complexe taak die voldoende regelmogelijkheden biedt kan het leergedrag in potentie stimuleren, maar dat hoeft niet altijd het geval te zijn. Kwantitatieve en kwalitatieve overbelasting, taakonderbrekingen en gebrek aan informatie 
om de taak uit te kunnen voeren kunnen de regulatie van de taak verstoren, wat ertoe kan leiden dat taakuitvoerders stress gaan ervaren en het leergedrag gehinderd wordt. In zulke gevallen zullen taakuitvoerders vaak geen nieuwe doelen en actieprogramma's ontwikkelen, maar vervallen in reeds geautomatiseerd gedrag (Frese \& Zapf, I994; Pomaki, Maes \& Ter Doest, 2004). Daarnaast maken regulatieproblemen het moeilijk om de feedbackcyclus te voltooien; het werk komt nooit af, zodat de afwezigheid van informatie over de resultaten van het eigen handelen het onmogelijk maakt om iets te leren. Het verband tussen taakeisen en leermogelijkheden is dus maar tot op zekere hoogte positief; voorbij een bepaald niveau van regulatievereisten zullen de leermogelijkheden (vanwege regulatieproblemen) weer afnemen.

Regelmogelijkheden. Een tweede belangrijke variabele in de HT betreft de regelmogelijkheden waarover taakuitvoerders beschikken. Net zoals in het DC-model wordt in de HT controle gedefinieerd als de zeggenschap die taakuitvoerders heb80 ben over wat er gedaan moet worden (welke doelen moeten er worden behaald?), en wanneer en hoe dat dient te gebeuren (welk actieprogramma wordt er gebruikt?). Het hebben van veel regelmogelijkheden betekent dat men kan kiezen tussen verschillende handelingsplannen om een doel te bereiken; wanneer die vrijheid ontbreekt (er zijn bijvoorbeeld geen haalbare alternatieve actieprogramma's) is er geen sprake van beslissingsvrijheid.

Het hebben van veel regelmogelijkheden kan het leren op twee manieren faciliteren. Allereerst kunnen takuitvoerders met veel regelmogelijkheden grotendeels hun eigen doelen bepalen. Ze kunnen nieuwe actieprogramma's ontwikkelen en kunnen besluiten welke nieuwe vaardigheden zij moeten leren om deze programma's uit te voeren. Ten tweede kunnen taakuitvoerders met veel regelmogelijkheden zelf besluiten welke actieprogramma's zij willen gebruiken om bestaande doelen te realiseren. Het is om beide redenen aannemelijk dat taakuitvoerders die beschikken over veel regelmogelijkheden relatief veel leergedrag dan wel persoonlijkheidsontwikkeling zullen vertonen.

Feedback. Het ontvangen van feedback is een noodzakelijke voorwaarde om te kunnen leren. Feedback dient verschillende doelen in het leerproces: (I) zonder feedback kunnen taakuitvoerders hun gedrag niet koppelen aan een bepaalde uitkomst (Bandura, 1997); (2) feedback laat zien in hoeverre men het te bereiken doel genaderd is en geeft informatie over de effectiviteit van het uitgevoerde actieprogramma; (3) positieve feedback (de realisatie van het te behalen doel) vertelt taakuitvoerders over welke vaardigheden zij beschikken; negatieve feedback (bijvoorbeeld fouten) laat zien welke vaardigheden zij nog niet beheersen.

Interpersoonlijke verschillen. Een belangrijke veronderstelling in de HT is dat taakuitvoerders vorm geven aan hun werkomgeving. Het is echter aannemelijk dat taakuitvoerders verschillen in de manier waarop zij dat doen, wat kan betekenen dat de ene taakuitvoerder méér zal leren dan de andere. Maar welke typen interpersoonlijke verschillen zijn hierbij relevant? Alhoewel dit geen centraal punt is in de HT, hebben verschillende onderzoekers zich met dit onderwerp beziggehouden. In principe kunnen interpersoonlijke verschillen betrekking hebben op ten eerste de motivatie om nieuwe vaardigheden aan te leren, en ten tweede op de mate waarin taakuitvoerders beschikken over de vaardigheden en cognities om effectief vorm te geven aan hun omgeving (actiestijlen). 
Wat betreft de motivatie om nieuwe vaardigheden aan te leren: de doeloriëntatiebenadering (Harackiewicz \& Sansone, I99I) stelt dat waar de een primair gemotiveerd wordt door de wens te laten zien dat men competenter is dan een ander (dat wil zeggen, een prestatiedoel nastreeft), wil de ander vooral de eigen competentie verder ontwikkelen (men streeft een leerdoel na). Deze tweede oriëntatie zou gepaard moeten gaan met een hoge motivatie om te leren (Van Yperen, 2003). In overeenstemming met deze aanname hebben mensen met een leeroriëntatie meer behoefte aan feedback dan anderen (Ashford, Blatt \& VandeWalle, 2003, voor een review). Anderzijds is nog onduidelijk of er inderdaad een positieve relatie is tussen het hebben van een leeroriëntatie en feitelijke prestatie. Eerder onderzoek kon een dergelijke samenhang niet altijd bevestigen (bijvoorbeeld Fisher \& Ford, I998; Heimbeck, Frese, Sonnentag \& Keith, 2003). Vooralsnog is de relatie tussen doeloriëntatie (opgevat als de motivatie om te leren) en leergedrag (met name de met het leren samenhangende prestatie) dus onduidelijk.

Wat betreft de cognities en vaardigheden om te leren: de HT veronderstelt dat het handelen (waaronder het leren) wordt beïnvloed door actiestijlen, refererend aan concepten als (I) doeloriëntatie en planmatigheid, en (2) persoonlijk initiatief. Planmatigheid en doeloriëntatie als actiestijl refereren aan de mate waarin taakuitvoerders gedetailleerde lange-termijndoelen ontwikkelen en daaraan vasthouden. Beide actiestijlen zouden zijn gerelateerd aan persoonlijkheidskenmerken (bijvoorbeeld zorgvuldigheid), en zich daarnaast ontwikkelen als functie van taakkenmerken (zoals regelmogelijkheden) en oefening (Frese, Fay, Hilburger \& Leng, I997; Frese \& Zapf, 1994). Personen met een hoge mate van persoonlijk initiatief (PI, Frese, 200I) zijn geneigd hun eigen doelen te stellen, zoeken naar feedback en proberen problemen vóór te zijn. Dergelijke personen zullen vermoedelijk vaker nieuwe vaardigheden verwerven dan anderen. In overeenstemming hiermee vonden Parker en Sprigg (1999) dat takuitvoerders die hoge taakeisen en veel autonomie rapporteerden (en die dus veel zouden moeten leren) aangaven over veel zelfvertrouwen te beschikken; dit gold echter uitsluitend voor diegenen met een proactieve oriëntatie. Samenvattend, er zijn redenen om te verwachten dat interpersoonlijke verschillen van invloed zijn op het leergedrag van taakuitvoerders. Empirisch onderzoek naar deze kwestie is echter afwezig of (deels) inconsistent met de verwachting (zie het onderzoek naar doeloriëntatie en leergedrag/prestatie). Verder onderzoek naar deze kwestie lijkt daarom onmisbaar om meer inzicht in de rol van dergelijke verschillen in het leerproces te verwerven. Het is bijvoorbeeld mogelijk dat taakuitvoerders met een leeroriëntatie zich weliswaar eigen doelen stellen, maar dat leergedrag alleen zal optreden bij diegenen die daarnaast een adequaat handelingsplan ontwikkelen om deze doelen te bereiken.

\section{Het Demand-Control-model versus de handelingstheorie}

Eerder concludeerden we dat Karaseks (1979) DC-model weinig inzicht verschaft in de aard van de effecten van werkkenmerken op het leergedrag. We stelden vervolgens dat de HT (Hacker, I998) meer inzicht zou kunnen geven in deze relatie. 
Maar in welke opzichten verschillen beide benaderingen, zijn ze te combineren, en levert die combinatie nieuwe perspectieven en onderzoeksvragen op? Hieronder vergelijken we eerst de centrale concepten en assumpties van het DC-model en HT. Daarna presenteren we een geïntegreerd model, dat vervolgens gebruikt wordt om richtingen voor nieuw onderzoek naar de relatie tussen taakkenmerken en leergedrag aan te geven.

\subsection{Vergelijking van modellen}

In deze paragraaf bespreken we de overeenkomsten en verschillen tussen het DCmodel en HT op de volgende punten: (I) de conceptualisatie van leergedrag; (2) de conceptualisatie van werk (wat zijn de centrale kenmerken daarvan?); (3) de mechanismen die werkkenmerken met leergedrag verbinden; en (4) de taakuitvoerder en diens interactie met de werkomgeving.

82 Conceptualisatie van leergedrag. Hierboven bespraken we de overeenkomsten tussen actief leergedrag en persoonlijkheidsontwikkeling. Hoewel het DC-model niet altijd even duidelijk is over hetgeen actief leren inhoudt, lijkt het erop dat beide concepten ruwweg equivalent zijn. Het DC-model en de HT beogen dus grotendeels hetzelfde concept te verklaren. Merk overigens op dat het verwerven van nieuwe vaardigheden in beide benaderingen impliciet als iets positiefs en nastrevenswaardigs wordt gezien. Het is echter denkbaar dat takuitvoerders tijdens de uitvoering van hun taak vaardigheden verwerven die minder positief geduid moeten worden. Werknemers kunnen zich bijvoorbeeld een werkhouding aanleren die weliswaar tot hogere productie leidt maar die op termijn ook RSI-klachten teweeg kan brengen; de chef van de werkplaats kan zich ontwikkelen tot een kleine dictator die wellicht zélf veel werkgerelateerd zelfvertrouwen ervaart, maar die tegelijkertijd een nefaste invloed heeft op het welzijn en de productiviteit van zijn (of haar) ondergeschikten. Anders gezegd, nieuwe vaardigheden kunnen dysfunctioneel zijn, zowel voor de taakuitvoerder, degenen in zijn/haar omgeving, als de organisatie waarvoor hij/zij werkzaam is.

Centrale werkkenmerken. Regelmogelijkheden en taakeisen zijn de twee centrale werkkenmerken van het DC-model. Alhoewel taakeisen gewoonlijk worden gemeten in termen van kwantitatieve taakeisen en tijdsdruk (Karasek, I985), heeft dit concept een bredere lading waartoe bijvoorbeeld ook kwalitatieve taakeisen behoren (meer algemeen spreken Karasek \& Theorell [1990, p. 34] van de 'objective requirements of a situation'). Deze laatste definitie lijkt op de notie van regelvereisten in de HT, die betrekking heeft op taakcomplexiteit, taakinterrupties, en kwantitatieve én kwalitatieve eisen. Taakeisen en regelvereisten overlappen elkaar dus in sterke mate. Op dezelfde manier refereren taakcontrole en regelmogelijkheden aan dezelfde onderliggende concepten, namelijk de zeggenschap die men heeft over de dingen die men doet, de manier waarop men deze uitvoert en wanneer men deze doet.

Deze overeenkomsten strekken zich uit tot de leergerelateerde hypothesen in beide benaderingen. Het DC-model veronderstelt dat het hebben van veel taakeisen en veel controle ertoe leidt dat taakuitvoerders actief leergedrag gaan vertonen. De combinatie van weinig taakeisen en weinig controle leidt tot het verlies van vaardigheden. De HT beargumenteert dat men nieuwe vaardigheden zal verwerven als (I) de regelmogelijkheden van de situatie overeenkomen met de regelvereisten, terwijl 
zowel hoge regelmogelijkheden als hoge regelvereisten de kans op persoonlijkheidsontwikkeling doen toenemen; en (2) taakuitvoerders de feedbackcyclus kunnen doorlopen (men kan doelen stellen, plannen om deze doelen te bereiken ontwikkelen en uitvoeren, en de resultaten van het handelen kunnen worden geëvalueerd). Operationeel veronderstellen beide benaderingen dus dat de combinatie van hoge taakeisen (regelvereisten) en veel controle (regelmogelijkheden) positieve gevolgen heeft voor het leergedrag (persoonlijkheidsontwikkeling).

Onderliggende mechanismen. Het DC-model veronderstelt dat de combinatie van veel taakeisen met veel controle taakuitvoerders de vrijheid geeft om op zoek te gaan naar de beste manier om met deze taakeisen om te gaan. Het is onduidelijk wat hiermee precies wordt bedoeld. Men kan bijvoorbeeld zowel 'trial and error'-gedrag gaan vertonen, als systematisch gaan experimenteren met allerlei manieren om de taak uit te voeren. Interpersoonlijke verschillen zijn grotendeels irrelevant; alle taakuitvoerders worden geacht op dezelfde manier te reageren op bepaalde combinaties van taakkenmerken. De HT benadrukt daarentegen sterk de rol van zelfregulerende processen bij het verwerven van nieuwe vaardigheden. Het zichzelf stellen van nieuwe doelen impliceert dat men nieuwe vaardigheden moet verwerven om dat doel te bereiken. Feedback is van essentieel belang; zonder kennis van de resultaten van het eigen handelen kan men geen nieuwe kennis verwerven. Interpersoonlijke verschillen kunnen het leerproces beïnvloeden, hetzij omdat sommige taakuitvoerders meer gemotiveerd zijn om te leren, hetzij omdat taakuitvoerders verschillen in de mate waarin ze de vaardigheden en cognities bezitten om hun omgeving te kunnen beïnvloeden.

Beide benaderingen veronderstellen dat het leergedrag invloed heeft op de perceptie van de werkomgeving. Het DC-model postuleert dat leergedrag effect heeft op de mate waarin men stress ervaart, wat kan leiden tot een veranderende perceptie van werkkenmerken (De Lange et al., 2005). De HT neemt aan dat leergedrag ertoe kan leiden dat taakuitvoerders zichzelf nieuwe doelen stellen, wat tegelijk de kenmerken van de taak verandert. Door het routiniseren van actieprogramma's is minder cognitieve regulatie (inspanning) nodig om de betreffende handelingen uit te voeren, waardoor de belasting die het actieprogramma oplevert vermindert.

De taakuitvoerder en diens interactie met de werkomgeving. In zijn vroegste formulering is het DC-model een stimulus-responsemodel: bepaalde werkkenmerken lokken als het ware automatisch leergedrag uit, onafhankelijk van de kenmerken van de taakuitvoerder. De HT veronderstelt daarentegen dat taakuitvoerders invloed uitoefenen op hun werkomgeving: ze stellen zichzelf doelen, kunnen de structuur van hun taak veranderen (door objectieve veranderingen in de taakinhoud of door aanpassing van hun perceptie van die taak). Hoewel latere formuleringen van het DCmodel (Karasek \& Theorell, 1990) stelden dat leergedrag ertoe kan leiden dat taakuitvoerders de kenmerken van hun taak anders percipiëren, biedt de HT beduidend meer ruimte voor een wisselwerking tussen de taakuitvoerder en diens omgeving. Daardoor is de HT meer een psychologische theorie dan het DC-model. 


\subsection{Integratie van het DC-model en handelingstheorie: een onderzoeks- agenda}

Onze vergelijking van de ideeën betreffende het DC-model en de HT heeft sterke gelijkenissen tussen beide benaderingen laten zien. We zijn niet de eersten die deze overeenkomsten opmerken (vergelijk Holman \& Wall, 2002). Refererend aan het werk van Hacker bespreken Karasek en Theorell (I990, p. I7I-I73) zelfs enige implicaties van HT voor hun DC-model, waarbij ze zich vooral richten op de relatie tussen stress en leergedrag. Ze erkennen dat er twee typen leergedrag moeten worden onderscheiden; namelijk open-loop learning (corresponderend met het ontwikkelen van nieuwe oplossingen voor toekomstige problemen) en closed-loop learning (het routiniseren van eerder ontwikkelde handelingsplannen). Het routiniseren van dergelijke plannen maakt cognitieve ruimte vrij die takuitvoerders kunnen aanwenden om nieuwe uitdagingen aan te gaan. Karasek en Theorell lijken zich niet te realiseren dat de HT flexibel en breed genoeg is om alle leergerelateerde voorspellingen van het DC-model te incorporeren, en dat de HT de in het DC-model bestaande kloof tussen werkkenmerken en leergedrag kan dichten. Op basis van de HT kan gemakkelijk een pendant van het DC-model geformuleerd worden, dat wil zeggen, een op handelingstheoretische principes gebaseerd model waarin de in het DCmodel veronderstelde associatie tussen controle, taakeisen en actief leergedrag wordt uitgewerkt. In zo'n model is ook ruimte voor concepten als doelen en actiestijlen, zodat inter- en intrapersoonlijke verschillen daarin kunnen passen. Figuur I presenteert een aanzet tot zo'n model. Dit model kan worden samengevat in vier proposities die gebaseerd zijn op de eerder besproken ideeën.

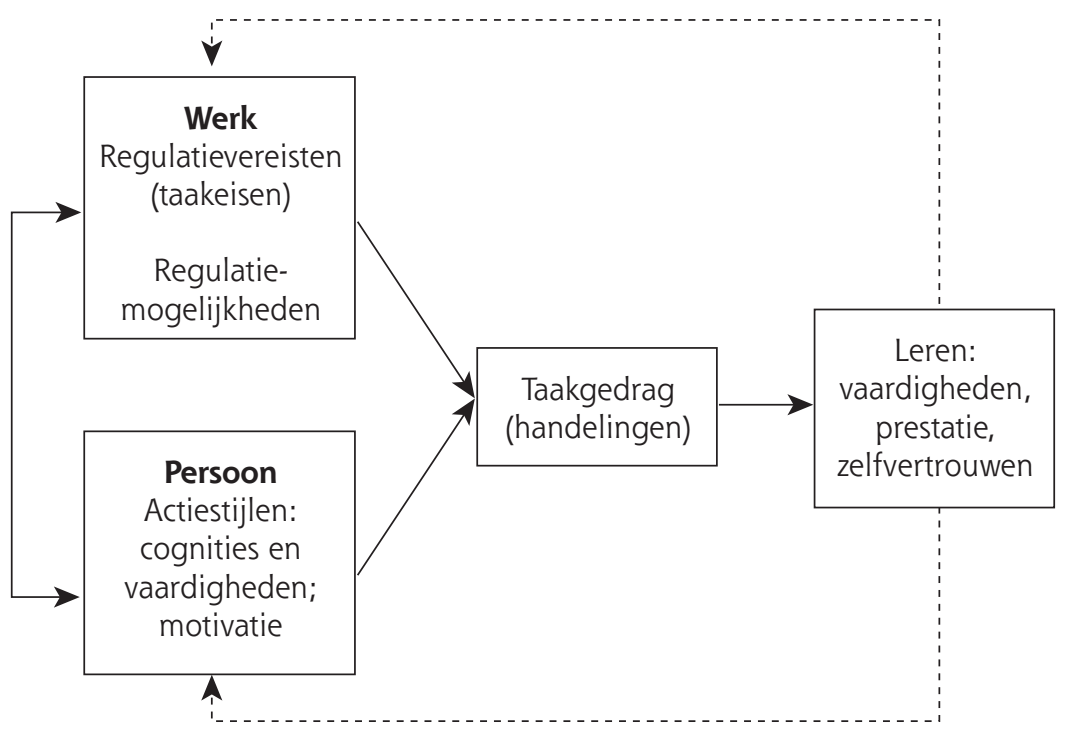

Figuur 1 Een heuristisch model voor de relaties tussen werkkenmerken, leergedrag, en interpersoonlijke verschillen 
1 Regelvereisten (ofwel taakeisen) en regelmogelijkheden (controle) zijn positief (maar niet lineair) gerelateerd aan taakgedrag (leren). $\mathrm{Er}$ is inmiddels enige evidentie voor deze stelling, grotendeels afkomstig uit onderzoek dat de actief-lerenhypothese van het DC-model toetste. In het eerste deel van deze bijdrage is dit bewijs kort besproken.

2 De effecten van regelvereisten en regelmogelijkheden worden gemedieerd door het taakgedrag. Dat wil zeggen, de regelvereisten en -mogelijkheden die door de taak worden geboden hebben invloed op de mate waarin takuitvoerders zichzelf doelen kunnen stellen en deze kunnen behalen door de feedbackcyclus te doorlopen.

3 Actiestijlen kunnen via het taakgedrag effect uitoefenen op het leren. Bepaalde actiestijlen (bijvoorbeeld een hoge mate van persoonlijk initiatief) stimuleren taakuitvoerders om zichzelf nieuwe doelen te stellen, zich te oriënteren op hun taak, handelingsplannen te ontwikkelen om hun doelen te bereiken, en deze uit te voeren. Andere actiestijlen kunnen verhinderen dat zij de feedbackcyclus voltooien, wat kan betekenen dat de betreffende uitvoerders weinig nieuwe vaardigheden verwerven.

4 Leergedrag leidt tot veranderingen in de taakuitvoerders, alsmede in bun werkomgeving. Het verwerven van nieuwe vaardigheden wordt geacht te leiden tot persoonlijkheidsontwikkeling. Taakuitvoerders kunnen meer zelfvertrouwen verkrijgen, wat ertoe kan leiden dat hun actiestijlen en motivaties veranderen. Daarnaast kan het verwerven van nieuwe vaardigheden ertoe leiden dat taakuitvoerders zich nieuwe doelen stellen, wat hun regulatievereisten (werkbelasting) kan vergroten.

Op basis van deze proposities kan een agenda voor toekomstig onderzoek naar de relatie tussen werkkenmerken en leergedrag worden opgesteld. Wat betreft de relatie tussen werkkenmerken en leergedrag (onze eerste propositie) heeft eerder onderzoek laten zien dat een dergelijke relatie aanwezig is, in ieder geval voor controle: de resultaten zijn minder eenduidig voor de effecten van taakeisen. Op dit moment is het vooral belangrijk om eerdere bevindingen te repliceren met gebruikmaking van valide instrumenten om de onafhankelijke (werkkenmerken) en afhankelijke (leergedrag) concepten te meten. Daarbij zou vooral gebruik moeten worden gemaakt van longitudinale en experimentele onderzoeksdesigns; het stadium waarin cross-sectionele studies veel kunnen toevoegen aan ons begrip van deze materie is wel voorbij. Op dezelfde manier is het wenselijk dat er onderzoek wordt gedaan naar de mogelijke reciproque effecten tussen leergedrag en werkkenmerken, en tussen leergedrag en stress.

De tweede propositie stelde dat regulatievereisten en -mogelijkheden indirect, via het taakgedrag, invloed hebben op het leergedrag. Om deze propositie te toetsen zou nieuw onderzoek zich moeten richten op (a) het verband tussen taakkenmerken en het gedrag van taakuitvoerders gedurende de uitvoering van de taak (bijvoorbeeld het stellen van doelen); (b) het verband tussen het gedrag van taakuitvoerders tijdens de uitvoering van de taak en het leergedrag; en (c) de mate waarin het verband tussen taakkenmerken en leergedrag wordt gemedieerd door het taakgedrag. Deze onder- 
werpen kunnen zowel in surveystudies (bijvoorbeeld Pomaki et al., 2004) als in laboratoriumexperimenten worden bestudeerd.

De derde propositie is dat actiestijlen het leergedrag indirect beïnvloeden, omdat ze effect hebben op de manier waarop de feedbackcyclus wordt doorlopen. Handelingstheoretisch onderzoek heeft bijvoorbeeld concepten als Frese's (200I) persoonlijk initiatief bestudeerd. Het lijkt belangrijk om te onderzoeken of en in welke mate dergelijke concepten ook belangrijk zijn in de context van leerprocessen. Ten slotte veronderstelt ons model dat leergedrag zowel de taakuitvoerder (diens actiestijlen) als diens werkomgeving zal beïnvloeden (propositie 4). Taakvoerders zullen actief vorm geven aan hun omgeving, terwijl die omgeving tevens invloed uitoefent op de uitvoerders. Eerder onderzoek naar de relatie tussen strain en werkkenmerken heeft laten zien dat deze elkaar over en weer over de tijd beïnvloeden (De Lange et al., 2005, voor een overzicht); zowel de HT als (zij het in mindere mate) het DCmodel veronderstelt dergelijke reciproque relaties voor de samenhang tussen werkkenmerken en leergedrag. Toekomstig onderzoek zou zich vaker moeten bezighouden met deze theoretisch interessante propositie.

Ten slotte moet opgemerkt worden dat alleen propositie I (werkkenmerken hebben effect op leergedrag) direct afgeleid kan worden uit Karasek en Theorell's (I990) DC-model, en dat het bewijs voor deze propositie zowel het DC-model als ons handelingstheoretische model ondersteunt. De andere drie proposities zijn in eerste instantie gebaseerd op handelingstheoretische inzichten en kunnen niet worden afgeleid uit het DC-model (met mogelijke uitzondering van propositie 4, omdat het DC-model expliciet stelt dat 'learning inhibits strain').

\section{Conclusies}

We stelden in deze bijdrage dat werkgerelateerd welzijn méér is dan alleen de afwezigheid van stress en ongezondheid; ook de aanwezigheid van positieve werkuitkomsten, zoals motivatie, competentie en leergedrag zou daaronder moeten vallen. Omdat leergedrag nog weinig aandacht heeft gekregen van onderzoekers in de arbeids- en gezondheidspsychologie, hebben we kort het bewijs voor de leergerelateerde voorspellingen van het in deze discipline populaire DC-model besproken (Karasek \& Theorell, 1990). Alhoewel deze voorspellingen grotendeels werden ondersteund, identificeerden we diverse conceptuele en methodologische tekortkomingen van dit onderzoek. Methodische problemen hadden betrekking op de afwezigheid van longitudinale onderzoeksdesigns en de veelal gebrekkige constructvaliditeit van zowel de afhankelijke als de onafhankelijke variabelen.

Het belangrijkste conceptuele probleem was dat het DC-model de psychologische processen die werkkenmerken met leergedrag verbinden nauwelijks specificeert, terwijl er weinig ruimte is voor interpersoonlijke verschillen. Daarom presenteerden we een theoretische benadering die in de arbeids- en gezondheidspsychologie tot op heden nauwelijks wordt toegepast, namelijk de HT. Na de overeenkomsten en verschillen tussen deze benadering en het DC-model te hebben besproken, presenteerden we een handelingstheoretisch model waarin de relaties tussen werkkenmerken, motivatie, vaardigheden, taakgedrag en leergedrag werden beschreven. Dit model is consistent met de 
bevindingen van DC-gebaseerd onderzoek, terwijl het ook aanknopingspunten biedt voor verder onderzoek naar de effecten van werkkenmerken op leergedrag (en vice versa). De belangrijkste conclusies van dit hoofdstuk kunnen worden samengevat in drie empirische en vier theoretische punten. De drie empirische punten zijn:

1 Werkkenmerken (controle en tot op zekere hoogte taakeisen) zijn gerelateerd aan leergedrag, zodanig dat hogere taakeisen en meer controle gewoonlijk gerelateerd zijn aan meer leergedrag (tenzij deze taakeisen extreem hoog zijn).

2 Vanwege de afwezigheid van longitudinale onderzoeksontwerpen kan weinig worden gezegd over de richting en de dynamiek van dit verband. De validiteit van de in het onderzoek naar de relaties tussen leren en werkkenmerken gebruikte instrumenten is niet overtuigend.

3 Er is weinig bekend over de effecten van interpersoonlijke verschillen of de structuur van het proces dat werkkenmerken met leergedrag verbindt; eerder onderzoek heeft dit onderwerp grotendeels genegeerd. Evenmin is er veel bekend over de relaties tussen leergedrag en stress; er zijn indicaties dat beide concepten gerelateerd zijn (Holman \& Wall, 2002; Taris \& Feij, 2005).

De theoretische punten zijn:

1 De in Karaseks (1979) DC-model en in de HT gebruikte concepten overlappen elkaar sterk. De bredere handelingstheoretische concepten omvatten de in het DC-model gebruikte concepten, in ieder geval op operationeel niveau. De leergedraggerelateerde voorspellingen zijn in beide benaderingen gelijk.

2 De HT reserveert een belangrijke plaats voor procedurele en cognitieve vaardigheden in het leerproces. In die zin lijkt de HT in staat om de black box tussen taakkenmerken en leergedrag te openen. Door de rol van cognities en vaardigheden te benadrukken maakt de HT het tevens mogelijk om interpersoonlijke verschillen te onderzoeken. In die zin is de handelingstheorie meer een (arbeids)psychologische theorie dan het DC-model.

3 Door nieuwe concepten te introduceren die de relatie tussen werkkenmerken en leergedrag kunnen mediëren, kan de HT nieuw licht werpen op deze relatie. De HT lijkt daarmee in staat nieuwe hypothesen te genereren betreffende deze relatie. Door deze hypothesen verder uit te werken en te toetsen kunnen we onze kennis van deze relatie verdiepen.

4 De handelingstheoretische inzichten betreffende de relatie tussen werkkenmerken en leergedrag kunnen worden weergegeven in een relatief eenvoudig heuristisch model (figuur 1). We denken dat dit model de in deze bijdrage besproken noties goed weergeeft en, belangrijker nog, dat het aanknopingspunten biedt voor onderzoek naar de manier waarop taakuitvoerders nieuwe vaardigheden verwerven - en de consequenties daarvan voor henzelf en hun omgeving.

\section{Literatuur}

Ashford, S.J., Blatt, R. \& VandeWalle, D. (2003). Reflections on the looking glass: A review of research on feedback-seeking behavior in organizations. Journal of Management, 29, 773-799.

Bandura, A. (1997). Self-efficacy: The exercise of control. New York: Freeman.

Berlew, D.E. \& Hall, D.T. (I966). The socialization of managers: Effects of expectations on performance. Administrative Science Quarterly, II, 207-223. 
Brewer, W.F. (2003). Mental model. In L. Nadel (Red.), Encyclopedia of cognitive science, Vol. 3. London: Nature Publishing Group.

De Lange, A.H., Taris, T.W., Kompier, M.A.J., Houtman, I.L.D. \& Bongers, P.M. (2003). The very best of the millennium: Longitudinal research on the Job demands-Control model. Journal of Occupational Health Psychology, 8, 282-305.

De Lange, A.H., Taris, T.W., Kompier, M.A.J., Houtman, I.L.D. \& Bongers, P.M. (2005). How does mental health affect work characteristics? A longitudinal test of eight mechanisms. Scandinavian Journal of Work, Environment and Health, 3I, 3-I4.

De Rijk, A.E., Le Blanc, P.M., Schaufeli, W.B. \& De Jonge, J. (1998). Active coping and need for control as moderators of the job demand-control model: Effects on burnout. Journal of Occupational and Organizational Psychology, 7I, I-I8.

Fisher, S.L. \& Ford, J.K. (1998). Differential effects of learner effort and goal orientation on two learning outcomes. Personnel Psychology, 5I, 397-420.

Frese, M. (200I). Personal initiative (PI): The theoretical concept and empirical findings. In M. Erez, U. Kleinbeck \& H. Thierry (Red.), Work motivation in the context of a globalizing economy (pp. 99-IIo). Mahwah, NJ: Lawrence Erlbaum.

Frese, M., Fay, D., Hilburger, T. \& Leng, K. (1997). The concept of personal initiative: Operationalization, reliability and validity of two German samples. Journal of Occupational and Organizational Psychology, 70, 139-16r.

Frese, M. \& Zapf, D. (1994). Action as the core of work psychology: A German approach. In H.C. Triandis, M.D. Dunnette \& L.M. Hough (Red.), Handbook of Industrial and Organizational Psychology (Vol. 4, pp. 271-340). Palo Alto: Consulting Psychologists Press.

Geurts, S.A.E. \& Demerouti, E. (2003). Work-nonwork interface: A review of theories and findings. In M. Schabracq, J. Winnubst \& C. Cooper (Red.), Handbook of Work and Health Psychology (pp. 279-3I2). Chichester: Wiley.

Gollwitzer, P.M. (1999). Implementation intentions: Strong effects of simple plans. American Psychologist, 54, 493-503.

Hacker, W. (1998). Allgemeine Arbeitspsychologie: Psychische regulation von Arbeitstätigkeiten. Bern: Verlag Hans Huber.

Harackiewicz, J.M. \& Sansone, C. (I99I). Goals and intrinsic motivation: You can get there from here. In M.L. Maehr \& P.R. Pintrich (Red.), Advances in motivation and achievement (Vol. 7, pp. 2I-49). Greenwich, CT: JAI Press.

Heimbeck, D., Frese, M., Sonnentag, S. \& Keith, N. (2003). Integrating errors into the training process: The function of error management instructions and the role of goal orientation. Personnel Psychology, 56, 333-36r.

Holman, D.J. \& Wall, T.D. (2002). Work characteristics, learning-related outcomes, and strain: A test of competing direct effects, mediated, and moderated models. Journal of Occupational Health Psychology, 7, 283-301.

Karasek, R.A. (I976). The impact of the work environment on life outside the job. Stockholm: Institutet för Social Forskning.

Karasek, R.A. (1979). Job demands, job decision latitude, and mental strain: Implications for job design. Administrative Science Quarterly, 24, 285-308.

Karasek, R.A. (1985). Job Content Instrument: Questionnaire and user's guide. Los Angeles: Department of Industrial and Systems Engineering, University of Southern California.

Karasek, R. (1998). Demand-Control Model: A social, emotional, and physiological approach to stress risk and active behaviour development. In J.M. Stellmann (Red.), Encyclopaedia of occupational health and safety (4 ${ }^{\text {de }}$ editie, pp. 34.6-34.I4). Geneva: International Labour Office.

Karasek, R.A. \& Theorell, T. (1990). Healthy work: Stress, productivity, and the reconstruction of working life. New York: Basic Books.

Kristensen, T.S., Bjorner, J.B., Christensen, K.B. \& Borg, V. (2004). The distinction between work pace and working hours in the measurement of quantitative demands at work. Work \&' Stress, I8, 305-322. 
Kwakman, K. (1999). Leren van docenten tijdens de beroepsloopbaan: Studies naar professionaliteit op de werkplek in het voortgezet onderwijs. Nijmegen: Katholieke Universiteit Nijmegen.

Marsick, V.J. \& Watkins, K.E. (1990). Informal and incidental learning in the workplace. London: Routledge.

McCall, M.W., Lombardo, M.M. \& Morrison, A.M. (1988). The lessons of experience. Lexington, MA: Lexington Books.

McCauley, C.D., Ruderman, P.J.O. \& Morrow, J.E. (1994). Assessing the developmental components of managerial jobs. Journal of Applied Psychology, 79, 544-560.

Merllié, D. \& Paoli, P. (200I). Ten years of working conditions in the European Union. Dublin: European Foundation for the Improvement of Living and Working Conditions.

Parker, S.K. \& Sprigg, C.A. (I999). Minimizing strain and maximizing learning. Journal of Applied Psychology, 84, 925-939.

Pomaki, G., Maes, S. \& Ter Doest, L. (2004). Work conditions and employees' self-set goals: Goal processes enhance prediction of psychological distress and well-being. Personality and Social Psychology Bulletin, 30, 685-694.

Roe, R.A. \& Zijlstra, F.H.R. (I99I). Arbeidsanalyse ten behoeve van (her)ontwerp van functies: Een handelingstheoretische invalshoek. In J.A. Algera (Red.), Analyse van arbeid vanuit verschillende perspectieven (pp. 179-243). Lisse: Swets \& Zeitlinger.

Taris, T.W., De Lange, A.H., Kompier, M.A.J., Schaufeli, W.B. \& Schreurs, P.J.G. (2003). Learning new behavior patterns: A longitudinal test of Karasek's active learning hypothesis among Dutch teachers. Work E' Stress, I7, I-20.

Taris, T.W. \& Feij, J.A. (2005). Learning and strain among newcomers: A three-wave study on the effects of job demands and job control. Journal of Psychology, $138,543-563$

Taris, T.W. \& Kompier, M.A.J. (2004). Job characteristics and learning behavior. In P.L. Perrewé \& D.C. Ganster (Red.), Research in occupational stress and well-being: Exploring interpersonal dynamic (Vol. 4, pp. I27-I66). Amsterdam: JAI Press.

Van der Doef, M.P. \& Maes, S. (I999). The Job Demand-Control(-Support) Model and psychological well-being: A review of 20 years of empirical research. Work E' Stress, ${ }_{3} 3$, 87-II4.

Van Horn, J.E., Taris, T.W., Schaufeli, W.B. \& Schreurs, P.J.G. (2004). The structure of occupational well-being: A study among Dutch teachers. Journal of Occupational and Organizational Psychology, 77, 365-376.

Van Yperen, N.W. (2003). Task interest and actual performance: The moderating effects of assigned and adopted purpose goals. Journal of Personality and Social Psychology, 85, IOo6-IOI5.

Volpert, W. (1971). Sensumotorisches Lernen: Zur Theorie des Trainings in industrie und Sport. Frankfurt: Limpert.

Weiss, H.M. (I990). Learning theory and industrial and organizational psychology. In M.D. Dunnette \& L.M. Hough (Red.), Handbook of Industrial and Organizational Psychology, Vol. I (2 $2^{\text {de }}$ editie, pp. I71-22I). Palo Alto: Consulting Psychologists Press.

\section{Summary}

\section{Employee learning and task characteristics: An action-theoretical perspective}

Toon Taris, Michiel Kompier \& Etty Wielenga-Meijer, Gedrag \& Organisatie, Volume 19, Maart 2006, nr. 1, pp. 69-89

This study examines employee learning behavior as a function of task characteristics. Karasek and Theorell's (1990) Demand-Control (DC) model proposes that high levels of learning will occur when both job demands and job control are high. We consider the evidence for this assumption, arguing that the conceptual foundations of the DC model regarding the processes accounting for learning behavior are weak, 
while interpersonal differences in the learning process are largely neglected. We then discuss the relationship between learning and task characteristics from the perspective of German Action Theory (AT). AT explicitly discusses the mechanisms accounting for the relationship between task characteristics and learning, also assigning a role to interpersonal differences. Finally, we present a model that integrates action-theoretical insights on learning with DC-based empirical results.

Key words: employee learning, action theory, Demand-Control model, work characteristics 